\title{
From courses to a conservatoire:
} Issues of musical education Institutionalisation in Lithuania (I919 to 1949)

\author{
Danutè Petrauskaitè \\ Litovska akademija za glasbo in gledališce \\ Lithuanian Academy of Music and Theatre
}

\section{A Historical Review}

The musical culture of each country is always closely related to the political, economic, and social life. In terms of musical education in Lithuania, it should be emphasised that the first half of the $2 \mathrm{O}^{\text {th }}$ century was the period of gaining Lithuania's independence (1918), its consolidation (1919-1939), and loss (1940-1949). The state of Lithuania regularly faced the issue of its integrity: that was primarily because of Vilnius and its region which in the interwar years only episodicaly belonged to Lithuania; therefore, for almost two decades, the centre of the political and cultural life of the country was Kaunas, formerly a fortified city of Russia. Klaipeda Region was also specific, as for 700 years it was part of the state of Prussia, and since the late $19^{\text {th }}$ century, of the German Empire. Since the annexation of the Klaipeda Region to Lithuania in 1923 until the Anschluss of 1939, it enjoyed autonomy and preserved quite a few features of German culture, however, simultaneously it fostered Lithuanian traditions.

After surviving 120 years as part of Russia, including four decades of the Lithuanian press ban and the national culture suppression policy, in the $19^{\text {th }}$ century Lithuania was erased from the map of Europe and called by the tsarist administration the northwest region of the Russian Empire. It inherited both backward economy (thus, e. g., before 1924, Kaunas had no water or sewerage systems, and its main means of transport before 1929 was a horse-drawn tram, konké) and a Russian system of education as well 
as cities inhabited by foreigners. Despite all that, the Lithuanian nation preserved a healthy ethnic foundation, i. e., the Lithuanian village that produced a rather small, nonetheless, active cultural elite of peasant origin which predetermined the progress of an independent state. Over a dozen years of independence, Lithuania developed into a stable and integral state with strong strata of farmers and townspeople-officials, with increasing numbers of Lithuanian residents in cities, and with intellectuals having acquired education in universities abroad.

The development of the state ceased in 1940 when the USSR occupied and annexed Lithuania. Its physical and spiritual destruction began: deportation of people to Siberia, ruination of national heritage, and forced inculcation of the communist worldview. In 1944, as the Red Army was appropaching, over 80,000 of people, frightened by repressions, fled to the West. The majority of refugees were writers, composers, teachers, actors, and music performers. The second Soviet occupation lasted until 1990. The vacancies in schools and theatres were occupied by specialists and ideologists having come from Russia. The process of Sovietisation immediately affected the spheres of culture in education: thus, in 1945, a reform of music schools was launched.

\section{Establishment and Operation of Lithuanian Music Schools}

In the late $19^{\text {th }}$ and the early $20^{\text {th }}$ century, music in Lithuania could be learnt:

1. in the manors of noblemen where orchestra musicians were trained;

2. in Russian schools; and

3. by taking private lessons from foreign teachers.

However, Lithuania especially needed music teachers and church organists, and there were no institutions to train them. Moreover, at the very beginning of the $2 \mathrm{O}^{\text {th }}$ century, manor orchestras ceased to exist, Russian schools closed during the war, and just private teachers remained. One of them was Juozas Naujalis (1869-1934), a resident of Kaunas, an organist, and a graduate of the Warsaw Institute of Music; in 1892, he held the courses for organists at his own place; in 1913, they were reorganised into a school for organists and conductors. Soon afterwards, he had an idea of setting up a music school for everybody wishing to learn music. In 1917, he approached the Germans who controlled Kaunas at the time and received an official permission; however, he failed to find either premises or instruments, and the music school was 
not opened. After the political situation had changed and Lithuania became an independent state, Naujalis once again tried to realise his dream. He succeeded: in March 1919, the first private Lithuanian music school was launched in Kaunas.

The start was very modest due to the shortage of everything, from teachers to furniture. In the first years, the school had several teachers and about 40 pupils. As the three, and later five, rooms of the schools did not suffice, lessons sometimes were held at teachers' places. At that time, there were only three classes, those of piano, violin, and singing, and theoretical courses were not taught for some time. When a year later the Government demanded to give the premises to the Seimas Library, Naujalis transferred his school to the Lithuanian Society of Art Creators. Through the efforts of its members, on 1 October 1920 , it was nationalised, and Naujalis again became its director. In the course of several years, new teachers were invited, more classes appeared, and the number of the pupils tripled. In 1923, the school administration developed the first curriculum and named it the curriculum of the Lithuanian Conservatoire. That testified to the intentions of Naujalis to transform the school into a conservatoire, i. e. an institution of higher education, and to raise music teaching in Lithuania to a higher level.

\section{The Vision of the Lithuanian Conservatoire in the European Context}

The first professional Lithuanian musicians graduated from conservatoires in Russia (St. Petersburg, Moscow), Poland (Warsaw), Germany (Leipzig, Berlin), or Latvia (Riga), therefore, more than one of them cherished a dream to establish a conservatoire in Lithuania in order to protect young people from the hardships of studying abroad. In the early $2 \mathrm{O}^{\text {th }}$ century, Mikalojus Konstantinas Čiurlionis and Česlovas Sasnauskas spoke about it, and Stasys Šimkus also fostered the idea. They understood that only primary and secondary music schools did not suffice and a conservatoire was necessary to train high level performers, composers, and teachers, who in turn would lay the foundations for the national musical culture.

At that time, the oldest conservatoires in Europe were already enjoying over a hundred years of their experience, while others were still being established, as testified to by a table below: 
Table i: The dynamics of the establishment of conservatoires in Europe.

\begin{tabular}{cccc}
\hline 1771 & Stockholm & 1849 & Luxemburg \\
\hline 1795 & Paris & 1850 & Berlin \\
\hline 1807 & Milan & 1854 & Lviv \\
\hline 1811 & Prague & 1856 & Dresden \\
\hline 1814 & Florence & 1862 & Moscow \\
\hline 1821 & Vienna & 1866 & Munich \\
\hline 1821 & Warsaw & 1867 & Weimar \\
\hline 1822 & London & 1872 & Helsinki \\
\hline 1826 & Hague & 1882 & Amsterdam \\
\hline 1827 & Liége & 1884 & Oslo \\
\hline 1830 & Madrid & 1892 & Belgrade \\
\hline 1832 & Brussels & 1899 & Hamburg \\
\hline 1835 & Geneva & 1908 & Kiev \\
\hline 1836 & Lisbon & 1913 & Zagreb \\
\hline 1840 & Budapest & 1916 & Bratislava \\
\hline 1843 & Leipzig & 1919 & Ljubljana \\
\hline 1846 & Munich & 1919 & Riga \\
\hline 1847 & Barselona & 1919 & Tallinn \\
\hline 1848 & Dublin & 1919 & \\
\hline
\end{tabular}

Naujalis understood very well that Lithuania needed a conservatoire, therefore, thinking about the future, he made up his mind to develop a curriculum for a conservatoire instead of a music school. Not all the teachers supported his idea; some of them found it to be too early. Teacher of theory courses Juozas Žilevičius wrote:

it seems to me that our current music school is a secondary music school, just called a conservatoire in the curriculum. It would hardly be possible to call a school with such a curriculum a Lithuanian conservatoire [...]. Needless to say the music school is making a progress. In a dozen of years, of course, it will grow into a conservatoire.

Žilevičius proved to be right. The school had just several classes, it was short of teachers for a number of instruments, and it had no choir, orchestra, or library. That was noted by composer and choir conductor Stasys Šimkus (1887-1943) who had studied music in Warsaw, St. Petersburg, Leipzig, and Berlin. He dreamed of setting up a conservatoire in Vilnius, yet he had to 
think of another place after the ancient capital had been occupied by Poles. Klaipeda seemed to be the most suitable city for him. Having settled there, he opened a new music school in 1923 and called it a conservatoire.

\section{A Music School or a Conservatoire?}

It may seem strange why Šimkus did not settle in Kaunas where he was involved in the activity of the Lithuanian Society of Art Creators and for some time was even the leader of the Music Section. His decisions was predetermined by several reasons: a) a different understanding of a shortage of music professionals in Lithuania and b) the character of a choleric and a desire to act independently. In Kaunas Music School, in the first year of studies, the greatest attention was paid to the classes of piano, violin, singing, and organ, while Šimkus believed it had to train musicians for a symphony orchestra. The Opera House, established in Kaunas in 1920, hired musicians for its orchestra from restaurants and even from abroad. In the Opera House, the Russian and Yiddish languages predominated, and not every Lithuanian managed to immediately make himself understood in his native language. Šimkus thought it was a shame: the Opera House was one of the most prestigious art institutions in the provisional capital. Composer Vladas Jakubenas wrote:

Everything in Lithuania was gray, ugly, and poor - still opera emerged as good from the very beginning, [...] the Opera House became a kind of a sanctuary, it was loved by all, and the funds were flowing there. ${ }^{2}$

In the first year, the school which in German was called Memeler Konservatorium für Music operated as a private institution, and the courses were taught both in Lithuanian and in German. It offered a larger number of courses than Kaunas Music School at the time: e. g., the String Department had a cello class, and the Department of Wind Instruments, a clarinet class; students could study composition, and the classes of solfeggio and elementary music theory as well as the history of music were mandatory. That was because the school director Šimkus intended to train musicians for symphony orchestras and to get an official status of the conservatoire for the school. To that end, he bought musical instruments, invited teachers from abroad, and set up a dormitory for students. Due to the permanent

2 Vladas Jakubėnas, "Chorai, jų reikšmè ir organizacijos galimumai" [Choirs, their Significance, and Possibilities of Organisation], Vairas, no. 7-8 (1935): 352. 
shortage of funds, the director managed to persuade the Ministry of Education to take over the said educational institution. The Government of Lithuania complied with the request and nationalised the school on 1 January 1925.

Over the several subsequent years, Klaipeda Music School made rapid progress and outperformed the school of Kaunas: a symphony orchestra of teachers and students gave concerts all over Lithuania, the newly formed choir took part in local and national events, and the school boasted a library and a Museum of Music. It seemed to Šimkus that his dream came true, therefore, he replaced the word school by the word conservatoire both in the documents and the seal. That annoyed the Ministry of Education which understood a conservatoire as an institution of higher education and disliked the arbitrary use of the term, therefore, it ordered the school administration to change the name on the seal and letterheads as soon as possible. Deputy Director Juozas Žilevičius tried to object and explain that a) the Minister of Education himself allowed to Šimkus to call the school a conservatoire; b) in Germany, the term of a conservatoire was understood differently; c) the school worked under the curricula of Western European conservatoires and therefore had the right to the title, moreover, Kaunas Music School, which was not an institution of higher education, was also called a conservatoire. ${ }^{3}$ Unfortunately, the Ministry of Education could not be persuaded, and the desired title of a conservatoire had to be given up; however, it got established in the colloquial language, and especially among Germans.

Having nationalised Klaipeda Music School, the Ministry of Education felt it was too difficult for it to maintain two music schools in Lithuania. The idea was born to reorganise them by merging into one institution - a conservatoire. Needless to say, Klaipeda was not considered to be the right place for a conservatoire to operate. The authorities believed that a higher music school had to open in Kaunas, the then capital city of Lithuania, where musicians came after their studies abroad and where cultural and political life was in full swing. Even though 1/3 of all the Lithuanians in Lithuania Minor lived in Klaipeda, the city was alien to Lithuanian officials. Instead of consolidating the network of Lithuanian schools and organisations established there, the Government focused on Kaunas. Šimkus saw the

3 Juozas Žilevičius, "Letter to Councellor for Special Education of the Ministry of Education," 25. 5. 1928. The Archives of Lithuanian Literature and Art, f. 161, ap. 1, b. 90, p. 22. 
way out in the division of functions and gave a public lecture on the topic in Kaunas: he proposed to foster church music in Kaunas and to train orchestra musicians in Klaipeda. The teachers from Kaunas disagreed with such a plan, which led to protracted disputes. Šimkus managed at least to delay the process of reorganisation, which took five years. During the period, the classes of piano and singing were closed in Klaipeda, but its symphony orchestra stayed, and the first cohort of orchestra musicians over 50 of them - graduated from the school. Ultimately, in accordance with the Government resolution, the educational institution was closed in 1930. Just a small private music school was left, which was nationalised seven years later. In 1939, after the Nazi army had occupied Klaipeda, the school evacuated to Šiauliai and finished its existence in that city of Northern Lithuania.

\section{A Difficult Road to Recognition}

Even though Naujalis was criticised for his curriculum for the Lithuanian Conservatoire developed in 1923, he did not give up his idea to set up a conservatoire. He kept gradually establishing new classes, set up a chamber orchestra, opened a library, and started giving public concerts following the example of Klaipeda. In 1925, a Statute of the Lithuanian Conservatoire was drafted and sent to the Ministry of Education. Its officials did not fully understand it, therefore, they had to be explained why new courses had to be included in the curriculum, why some traditions taken over from Russia had to be abandoned, and why it was necessary to focus on the western traditions. However, the explanations did not help: the Lithuanian Governent did not need a conservatoire. Naujalis did not have another choice than to resign from the position of the director due to weakened health and to leave the school to a young composer Juozas Gruodis (1884-1948).

The new director found the school with several dozens of teachers and over 200 students. Lectures and classes took place in a building consisting of 15 communicating classrooms, totally unsuitable for the purpose of education, and a small concert hall. Gruodis had to take care both of the school facilities and amenities and the staff, however, his main goal was to validate the status of the conservatoire. It took almost six years. In the first year, the structure of the studies was revised as well as the syllabi of the courses, and an updated statute was drafted following the examples of the higher music schools of Vienna, Munich, Leipzig, and Berlin; however, the officials did not change their mind and did not set up a conservatoire. 
Oficially they claimed that there were no funds for the construction of a new building, and behind the enthusiasts' back they spoke that Lithuanian was an agricultural country and did not need a higher music school. In addition, Šimkus still hoped to set up a conservatoire in Klaipeda and had difficulty negotiating with Gruodis. Thus, at the end of the 1920s, only two countries in Europe had no conservatoires: Albania and Lithuania.

On 9 October 1929, Gruodis and all the academic staff under him sent a memo to the Ministry of Education to the effect that an imperfect Law on State Music School, promulgated in 1921, forestalled the setting up of a conservatoire, even though it already existed de facto. The places for the amendment of the Law were indicated and the main arguments to justify the amendments were laid out: a) the science of music did not know halfway; it could not be compared to the field of general education, and half-educated amateurs were not suitable for the practical activities in music; b) citizens of Lithuania had to be provided with an opportunity of pursuing higher musical education in their Motherland, otherwise they were going to go abroad; c) graduates of the Conservatoire would fill vacancies in orchestras, choirs, schools, and the State Opera House, and d) the Conservatoire would bring together the best musicians and become an important centre of national culture. ${ }^{4}$ Gruodis believed that the Conservatoire had to be a universal educational institution set up in Kaunas and had to cover all the stages of performer and composer training, from the lowest to the highest.

In 1931, a jubilee of the nationalised Kaunas Music School was solemnly commemorated. On that occasion, Gruodis prepared an overview of its achievements and emphasised that the said educational institution, by working in accordance with the curricula of foreign conservatoires, gradually became a higher music school. It only had to get the amended law and the official recognition of the conservatoire. The Government ultimately started dealing with the law, however, instead of amending, they abolished it. Instead of the law, the Statute of the Conservatoire was approved which came into force on 1 September 1932 and was made public only on 23 January $1933 .^{5}$ The Statute named six main departments - those of composition, piano, organ, string instruments (violin, cello, harp, and double-bass), and singing and wind instruments (along with percussion instruments), as well

4 Memo of the administration and the staff of the Kaunas State Music School to the Ministry of Education, 9. 10. 1929, The Archives of Lithuanian Literature and Art, f. 84 , ap. 1, b. 3, 1. 2-7.

5 Antanas Smetona and Juozas Tūbelis, "Konservatorijos statutas" [Statute of the Conservatoire], Vyriausybės žinios, no. 404 (1933): 1-4. 
as general education courses - elementary music theory, solfeggio, harmony, music forms, symphonic instrumentation, compulsory piano, history of music, and aesthetics and ensemble; the duration of the studies was to be six to eight years (depending on the chosen specialism). Unfortunately, the document did not indicate that the conservatoire was an institution of a higher musical education, even though the definition "a conservatoire is a special higher music school, the chief music school in Lithuania" was previously proposed by Naujalis and Gruodis. It is difficult to explain why the Ministry ignored the definition. Possibly its officials thought that the word conservatoire was self-evident, or they deliberately avoided the term. Only Article 41 of the Statute stated that an attendee was to receive a diploma and the rights of higher education provided he completed the entire programme of the conservatoire and presented a certificate of a comprehensive secondary school. Not all the musicians were satisfied with the said document. Graduate of Klaipèda Music School Motiejus Budriūnas did not notice any new trends in the training of musicians and believed that the school simply extended the programmes of the same specialities training soloists. He wrote:

The contemporary music life shows that the times of solo virtuosos have passed. Today, even the best soloists try to get jobs in the opera or orchestra, or as conductors or music teachers, because it is no longer possible to survive on concerts [...], and in Lithuania, even the best soloist-virtuoso in the world would not survive one year on his concerts. [...] A teacher training department in our Music School ought to be one of its most important institutions. [...] Preparation of good music teachers is a must. It would be more rational to have an orchestra department instead of a high virtuoso course for instrumentalists as well as an opera department for singers. The school then would have not only to give more frequent symphonic concerts, but also to stage operas. A virtuoso course might be left only for pianists. Therefore, it seems that we need an entirely different school. ${ }^{6}$

Budriūnas also noted that the Statute of the Conservatoire did not mention choir conducting, and the academic staff were not called professors or associate professors, but teachers as in general education schools. However, his comments were ignored. The staff of Kaunas were happy 
with the approved Statute and the Order of the Minister of Education of 7 February 1933 by which Kaunas Music School was closed and a Conservatoire set up in its place. Neither the teachers ( 32 full time and freelance) nor the students (about 250) felt any changes. They just had to write applications for continuing work or studies in the same, only renamed, institution.

The Kaunas Conservatoire opening ceremony took place on April 1 in the State Opera House. The ceremony was attended by the President of Lithuania Antanas Smetona, ministers, foreign ambassadors, honourable representatives of the Church, and guests, including the Rector of the Latvian Conservatoire Jāzeps Vìtols. Gruodis made a speech to overview the development of teaching music in Lithuania and to emphasise the significance of the establishment of the Conservatoire:

Our country cannot boast treasures hidden in the earth or millions of soldiers. We can only win the right to live in dignity by raising our culture and especially art. Even science does not make the name of the country as famous as art. Science is more cosmopolitan: it sheds light and gets immersed in the common sea of culture, while art brings out characteristic features of the nation, keeps the nation alive, and makes it loved by all and honourable. Now, when we have the centre of the science of music, we expect our musical culture to develop faster.

\section{The Development of Kaunas Conservatoire and the Consequences of Occupation}

Kaunas Conservatoire was gradually growing and strengthening, and the number of its graduates kept increasing. In 1933, nine students graduated from it, and in 1937, there were 30 of them. Gruodis made every effort to update the curriculum and to include new courses, such as, e. g., counterpoint, canon, and fugue, that he himself taught to prospective composers and organists. However, tense administrative and academic work affected the poor health of Gruodis, therefore, in 1937, he resigned from the director's position yet stayed to teach. The Ministry of Education appointed another composer, graduate of Leipzig Conservatoire Kazimieras Viktoras Banaitis (1896-1963), as the director. He held the post until 1943 and had to survive an especially difficult period.

A. Mušaitis, "Kauno konservatorijos atidarymas" [Opening of Kaunas Conservatoire], Vairas, no. 5 (1933): 63. 
The first Soviet occupation turned the lives of the academic staff and the students upside down. Emissaries from Moscow or their protégés were sent to the Conservatoire, a circle of Marxism-Leninism was set up, and an atmosphere of fear was felt everywhere: nobody wanted to be pushed into cattle wagons and be exiled to Siberia. Musical compositions started to be classified as appropriate and inappropriate, and formalistic and realistic. Valuable Lithuanian compositions were taken from the State Radio to the paper factory, thus the library of the Conservatoire also had to be revised. The Bolshevik regime lasted for a year: on 22 June 1941 the Nazi Army entered Lithuania. Part of the people were happy that the red terror came to an end and naively believed in the possibility of agreeing with Germans and restoring independent Lithuania.

Unfortunately, the brown terror started. The Conservatoire lost all the Jewish teachers and students: all of them were taken to the ghetto. Most of them perished there, and only a few survived. Some of the classrooms were occupied by German soldiers; moreover, in accordance with the instructions of the Nazi authorities, the works of Jewish and Russian composers were removed from the academic syllabi and concert repertoires. However, the Germans did not interfere with the very academic process as did Russians before them; only in 1943, when they felt that the war situation was becoming unfavourable for them, they took measures of repression against Lithuanian intellectuals who refused to assist in the formation of the SS divisions. In March, 46 people were arrested, including writers, teachers, publishers, and priests, and imprisoned in Stutthof concentration camp, while the universities operating in Lithuania as well as Kaunas Conservatoire were closed. Gruodis gave lessons in his own home, but the work was not really productive. The Conservatoire opened again in the autumn of 1944, when the war was coming to an end. Its director was graduate of Kaunas Conservatoire, violinist Kazys Matiukas (1909-1978). No stability or institutional development could be expected, as, with the approach of the Red Army, part of the teachers and students fled to the West along with multi-thousand crowds of Lithuanians. New academic staff and new premises had to be found. The Conservatoire succeeded in getting a three-storeyed palace, which had to be decorated with the portraits of Stalin. The children of dispossessed kulaks were forbidden to study in the Conservatoire. Not everyone was able to adjust to the conditions: in 1948, Gruodis died, and Matiukas resigned from the position. The latter was replaced by bassoonist Kazys Paulauskas (1903-1977), alumnus of Klaipeda 
Music School. Paradoxically, even if he did not have a diploma of higher education, he was approved as the head of the higher school in which he was also teaching. That meant that Klaipeda Music School was a conservatoire de facto, just the Government of Lithuania did not have enough resolution or money to fund two higher music schools. The same story repeated almost 20 years later, after Lithuania had regained its ancient capital Vilnius.

\section{Did Lithuania Need Two Conservatoires?}

In the interwar period, Vilnius had Mieczysław Karłowicz Conservatoire and the Jewish Music Institute. Both institutions worked under the curricula of European conservatoires. In order to integrate those schools into the common education system in Lithuania, the Soviet authorities reorganised them into courses, and later, on 1 October 1940, on their basis established Vilnius State Music School. Jonas Bendorius (1889-1954), a graduate from Leipzig Conservatoire of Music, became its director. At the time, it was one of the largest schools in the Baltic countries. In the first academic year, it boasted 73 teachers and about 650 students. ${ }^{8}$ It was to have been reorganised into a conservatoire in a year's time, but the plans were prevented by the war. Despite that, with the permission of the German authorities, in 1942, the school started work in accordance with the curriculum of Kaunas Music School. However, after the Nazis had killed Jewish teachers and students and had closed the main higher schools of Lithuania in 1943, the survival of the school became a serious issue. The school was saved through hiding under the status of a secondary school. Even though the school worked under the curriculum of the conservatoire, it did not have the right to issue conservatoire diplomas to their students, therefore the latter had to go to Kaunas to take their final exams. The emigration at the end of the war further exacerbated the crises and halved the number of teachers and students. Nonetheless, it did not affect the establishment of the conservatoire at that time, with the laws of the USSR having come into force: the music education had to be transformed into three cycles - primary, secondary, and higher. That's why, on the resolution of the Council of People's Comissars, on 1 January 1945, a conservatoire was established in Vilnius, and a children's music school was set up on the basis of junior forms and later developed into Čiurlionis Art Gymnazium; the middle chain between them was the

8 A letter of Jonas Bendorius to the chair of the Artistic Affairs Council of the Lithuanian SSR, 27. 12. 1945, The Archives of Lithuanian Literature and Art, f. 410, ap. 1, b. $13,1.48$. 
music college called after composer and conductor Juozas Tallat-Kelpša. For some time, all those schools operated under one roof, however, after new premises had been received in the main street of Vilnius, Stalin Avenue, the Conservatoire moved there and stayed till the present time, only under a different name.

In the post-war years, the administration of Vilnius Conservatoire faced a number of problems, including a huge dropout of teachers and students. It was related to the repatriation of Poles, due to which the formation of some groups failed, some courses had to be given up, and the activities of the orchestra and chamber ensembles were disrupted. The Conservatoire administration found a way out: they invited students of the music colleges in Klaipèda, Panevèžys, and Šiauliai to Vilnius. Even though they were already prepared for the studies in the Conservatoire as performers, they lacked theoretical fundamentals, therefore they were offered preparatory courses. ${ }^{10}$ Some teachers from Kaunas were invited: in the spring of 1946, the academic staff consisted of 60 teachers, mainly Lithuanian, although there were also some newcomers from Russia. Due to the ideologisation of studies, the content of the syllabi and the concert repertoires had to be revised. Quite a few compositions of Russia and the USSR composers were included; after the 1948 Resolution of the Central Committee of the USSR, works of Sergei Prokofiev and Dmitri Shostakovich were banned, and some compositions of Lithuanian authors became undesirable in the academic repertoire. A department of Marxism-Leninism had to be opened, and the courses of the History of the USSR, Dialectical Materialism, Scientific Communism, and Military Training had to be taught. Teachers were forbidden to teach from foreign textbooks and had to rely on Russian literature alone. Everybody had to obey the instructions of the Moscow authorities: on them depended people's survival and work.

Since 1945, two conservatoires operated in Lithuania. The greatest attention was paid to Vilnius Conservatoire. After the attestation of those schools, Kaunas Conservatoire received the $3^{\text {rd }}$, and Vilnius Conservatoire, the $2^{\text {nd }}$ category. It soon became clear that the Government of the Lithuanian SSR did not intend to fund two conservatoires and was going to merge them,

9 In 1992, the Lithuanian State Conservatoire was renamed the Lithuanian Music Academy, and in 2004, the Lithuanian Academy of Music and Theatre.

10 Tamara Vainauskiené, "Vilniaus konservatorijos formavimasis ir raida 1940-1949 metais" [Formation and development of Vilnius Conservatoire in 1940-1949], Menotyra, no. 1 (2003): 47. 
therefore, the staff and students were invited to move to Vilnius. To this end, examination of teachers and students was carried out. The majority passed the examination and came to Vilnius, while those who refused to move or did not pass stayed in Kaunas and continued in a music colege called under composer Juozas Gruodis in 1948. In 1949, both conservatories merged into the State Conservatoire of the Lithuanian SSR. For the work and studies in the institution, consisting of six faculties (Piano, Orchestra, Singing, Choir Conducting, Theory and Composition, and Theatrical Art), 84 teachers and 232 students were selected. ${ }^{\text {II }}$ The Ministry of Education appointed pianist Jurgis Karnavičius (1912-2001) as the Rector of the Conservatoire, and a new period in its history began.

\section{The Influence of Foreign Schools on the Training of Performers, Composers, and Music Teachers in Lithuania}

The academic staff in Lithuanian music schools and conservatoires were Lithuanian teachers - graduates of colleges or conservatoires abroad as well as foreign nationals from other countries. All of them taught in the way they had been taught and set up schools following the examples of foreign institutions. The table below presents a list of schools where teachers of Lithuania studied. They made use of the curricula of those schools and of the methodologies of teaching theoretical and practical courses they had mastered abroad.

\section{Table 2: Numbers of Lithuanian conservatoires' teachers - graduates of schools abroad ${ }^{12}$}

\begin{tabular}{|c|c|c|c|c|c|}
\hline No. & Cities & $\begin{array}{c}\text { Number of teachers } \\
\text { in Kaunas }\end{array}$ & $\begin{array}{l}\text { Number of teachers } \\
\text { in Klaipeda }\end{array}$ & $\begin{array}{c}\text { Number of teachers } \\
\text { in Vilnius }\end{array}$ & Total \\
\hline 1. & Berlin & 2 & 5 & 2 & 9 \\
\hline 2. & Budapest & - & 8 & - & 8 \\
\hline 3. & Cologne & - & 1 & - & 1 \\
\hline 4. & Dresden & - & - & 1 & 1 \\
\hline 5. & Krakow & - & - & 1 & 1 \\
\hline 6. & Leipzig & 6 & 1 & 1 & 8 \\
\hline 7. & Lodz & 1 & - & - & 1 \\
\hline 8. & Lviv & - & - & 1 & 1 \\
\hline 9. & Mannheim & - & 1 & - & 1 \\
\hline 11 & A certificate, & Archives of Lithua & an Literature and & $r \mathrm{t}, \mathrm{f} .410$, ap. 1 , b. 2 & 1. 45 \\
\hline 12 & $\begin{array}{l}\text { The table did } \\
\text { hius Schools, } \\
\text { ions they gai }\end{array}$ & $\begin{array}{l}\text { include absolutely } \\
t \text { was not always } \mathrm{p} \\
\text { music education. }\end{array}$ & $\begin{array}{l}\text { l the teachers of th } \\
\text { sible to determin }\end{array}$ & $\begin{array}{l}\text { Kaunas, Klaipeda, } \\
\text { where and in which }\end{array}$ & $\begin{array}{l}\text { nd Vil- } \\
\text { nstitu- }\end{array}$ \\
\hline
\end{tabular}




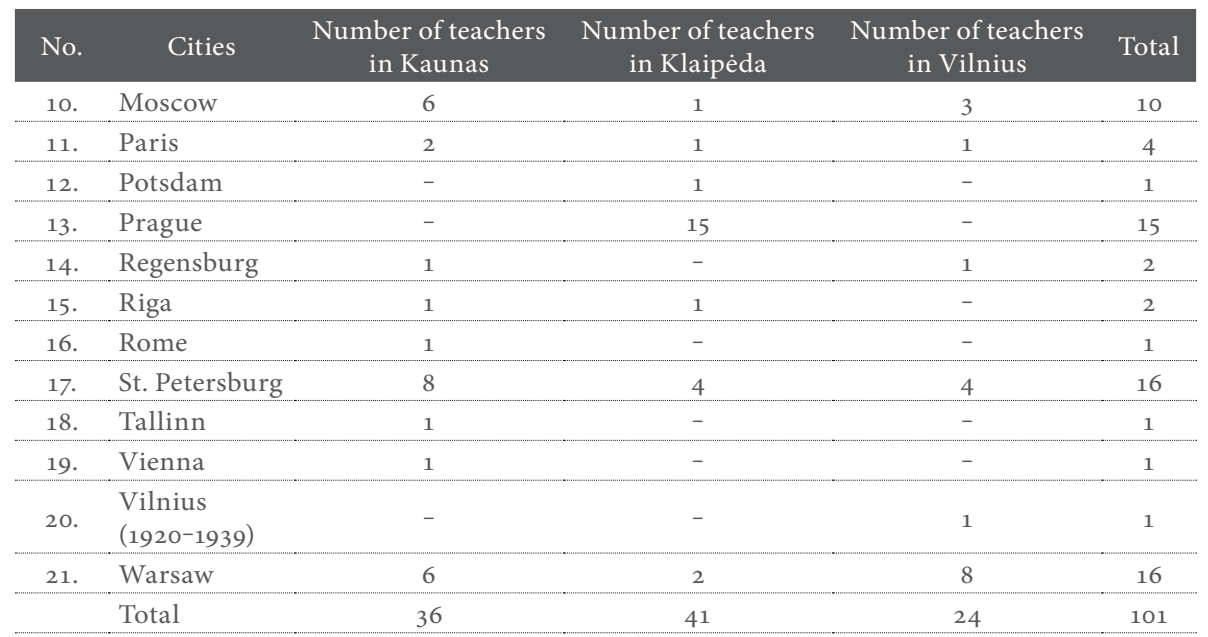

As can be seen from the table, the training of professional Lithuanian musicians was most strongly affected by the Russian, German, Polish, Czech, and Hungarian schools. Czechs and Hungarians concentrated in Klaipeda where they trained high-level wind instrumentalists and some string instrument performers. The German as well as the Polish and Russian schools were referred to both in Klaipeda and Kaunas, as Naujalis had studied in Warsaw and Regensburg, Šimkus in Warsaw, St. Petersburg, Leipzig, and Berlin, and Bendorius, in Warsaw and Leipzig. Most teachers in Vilnius had studied in Poland. Sometimes the impact was not direct: it came through other schools. Thus, e. g., Gruodis, who opened a division of composition in Kaunas, relied on the curricula developed for Riga Conservatoire by Jāzeps Vìtols, former graduate and professor of St. Petersburg State Conservatoire, and based on the Russian experience. St. Petersburg Conservatoire had quite a few teachers from Italy, Germany, and France, therefore, it would be difficult now to evaluate the constribution of one or another school. However, it is an obvious fact that all those teachers contributed to the development of the system of music education in Lithuania and provided it with diversity and attractiveness. Only after the establishment of the Soviet regime in Lithuania the diversity was eliminated: everybody had to follow the curricula sent from Moscow and to carry out the accompanying instructions. However, the Lithuanian Conservatoire remained Lithuanian even in the most complex periods and managed to preserve the experience gained from the foreign countries. 


\section{Bibliography}

A certificate, The Archives of Lithuanian Literature and Art, f. 410, ap. 1, b. 2, 1. 45.

A letter of Jonas Bendorius to the chair of the Artistic Affairs Council of the Lithuanian SSR, 27. 12. 1945, The Archives of Lithuanian Literature and Art, f. 410, ap. 1, b. 13, 1. 48.

Ambrazas, Algirdas Jonas, ed. Lietuvos muzikosistorija. II knyga. Nepriklausomybès metai 1918-1940 (Vilnius: Lietuvos muzikos ir teatro akademija, 2009).

Blūšius, Vytautas, ed. Kauno Juozo Gruodžio konservatorija (Kaunas: Spindulys, 2000).

Budriūnas, Motiejus. "Dèl Lietuvos konservatorijos statuto" [On the Statute of the Lithuanian Conservatoire]. Muzikos barai, no. 10-11 (1932): 139-140.

Jakubėnas, Vladas. "Chorai, jų reikšmè ir organizacijos galimumai” [Choirs, their Significance, and Possibilities of Organisation]. Vairas, no. 7-8 (1935): 351-355.

Memo of the administration and the staff of the Kaunas State Music School to the Ministry of Education, 9. 10. 1929, The Archives of Lithuanian Literature and Art, f. 84, ap. 1, b. 3, 1. 2-7.

Mušaitis, A. "Kauno konservatorijos atidarymas" [Opening of Kaunas Conservatoire]. Vairas, no. 5 (1933): 61-63.

Petrauskaitė, Danutè. Klaipédos muzikos mokykla 1923-1939 (Klaipėda: Klaipėdos universiteto leidykla, 1997).

Smetona, Antanas, and Juozas Tūbelis. "Konservatorijos statutas" [The Statue of the Conservatoire]. Vyriausybès žinios, no. 404 (23. 1. 1933): 1-4.

Vainauskienè, Tamara. "Vilniaus konservatorijos formavimasis ir raida 1940-1949 metais"+ [Formation and development of the Vilnius Conservatoire in 19401949], Menotyra, no. 1 (2003): 43-50.

Žilevičius, Juozas. "Valstybinè muzikos mokykla Kaune" [A State Music School in Kaunas]. Muzikos almanachas (1924): 94-101.

Žilevičius, Juozas. "Letter to Councellor for Special Education of the Ministry of Education." 25. 5. 1928, The Archives of Lithuanian Literature and Art, f. 161, ap. 1, b. 9o, p. 22. 